Available online at HISTORIA; Jurnal Pendidik dan Peneliti Sejarah
Jurnal homepage: https://ejournal.upi.edu/index.php/historia

\title{
PERAN INTELIJEN DAN PERANG PSIKOLOGIS PADA AGRESIVITAS KAMPANYE MILITER KEKAISARAN GENGHIS KHAN
}

\author{
Novky Asmoro, Syaiful Anwar, Syamsul Maarif \\ Prodi. Ilmu Pertahanan, Universitas Pertahanan Republik Indonesia \\ novky.asmoro@idu.ac.id
}

\begin{abstract}
To cite this article: Asmoro, N., ANwar, S., \& Maarif, S. (2021). Peran Intelijen dan perang psikologis pada agresivitas kampanye militer kekaisaran genghis khan. HISTORIA: Jurnal Pendidik dan Peneliti Sejarah, 4(2), 151-158. https://doi. org/10.17509/historia.v4i2.32879.
\end{abstract}

Naskah diterima : 21 Maret 2021, Naskah direvisi : 20 Mei 2021, Naskah disetujui : 7 Juni 2021

\begin{abstract}
The Mongol Empire, which prevailed in the 13th to 14th centuries, was one of the largest empires known in the history of world conquest. The stretch of the empire formed by Genghis Khan almost covers all of Eurasia, whose success story cannot be separated from the exploits of intelligence and psychological warfare that have been applied just like modern wars centuries after. Historical Research analysis in this article will try to juxtapose intelligence theories and psychological warfare so that the story of the Mongolian empire can be a valuable lesson for the study of strategy and philosophy of war as a reference for modern military strategy. The historical analysis process is expected to achieve the research objectives, namely to reveal the extent to which the role of intelligence and psychological warfare has an important position in supporting the successful expansion and success of the empiric Genghis Khan. The success of the Mongols in expanding their colonies was due to several factors, including the strength of leadership and Genghis Khan's ingenuity in mobilizing intelligence processes and psychological warfare based on elements of terrain and climate, infrastructure, the confidentiality of information and regulations. On the other hand, three factors caused the Mongol empire to collapse: internal conflicts, a change in vision from psychological warfare due to cultural acculturation, and the emergence of new nations that were more resilient in utilizing military alliances, geographical advantages, and more modern war strategies.
\end{abstract}

Keywords: Defense Strategy; Genghis Khan; Intelligence; Military Campaign; Mongol Empire; Psychological Warfare.

\begin{abstract}
Abstrak
Kekaisaran Mongol yang berjaya pada masa abad 13 hingga 14 adalah salah satu imperium terluas yang dikenal dalam sejarah penaklukan dunia. Bentangan kekaisaran bentukan Genghis Khan ini hampir meliputi seluruh Eurasia yang kisah suksesnya tidak lepas dari sepak terjang intelijen dan perang psikologis yang sudah diterapkan selayaknya perang-perang modern berabad abad setelahnya. Analisis Historical Research pada artikel ini akan mencoba menyandingkan teori-teori intelijen dan Perang Psikologis sehingga kisah imperium Mongolia tersebut dapat menjadi pelajaran berharga bagi kajian strategi dan ilmu filsafat perang sebagai referensi strategi militer modern. Proses analisis sejarah diharapkan mampu mencapai tujuan penelitian yakni mengungkap sejauh mana peran intelijen dan perang psikologis memiliki posisi penting dalam mendukung keberhasilan ekspansi dan kejayaan empirium Genghis Khan. Kesuksesan bangsa Mongol memperluas wilayah jajahannya disebabkan beberapa faktor diantaranya kekuatan leadership dan kecerdikan Genghis Khan dalam menggalang proses intelijen dan perang psikologis berdasarkan unsur medan dan iklim, infrastruktur, kerahasiaan berita dan regulasi. Di sisi lainnya, ada 3 faktor yang menyebabkan kekaisaran Mongol runtuh yakni konflik internal, perubahan visi dari perang psikologis akibat alkulturasi budaya dan munculnya bangsa-bangsa baru yang lebih tangguh dalam memanfaatkan aliansi militer, keunggulan geografis serta strategi perang yang lebih modern.
\end{abstract}

Kata Kunci: Genghis Khan; Intelijen; Kampanye Militer; Kekaisaran Mongol; Perang Psikologis; Strategi Pertahanan.

HISTORIA: Jurnal Pendidik dan Peneliti Sejarah, p-issn:2620-4789 | e-issn:2615-7993 


\section{PENDAHULUAN}

Mendiskusikan referensi dari sebuah strategi militer tentunya tidak bisa lepas dari analisis sejarah yang menyandarkan diri dari berbagai milestones peristiwa perang-perang kontemporer dunia. Dari sekian peristiwa kampanye militer yang populer di dunia, sejarah penaklukan bangsa Mongol lewat sang pemimpin agungnya Genghis Khan seolah tidak habis dikisahkan. Jika dirangkai, menurut Cleves (1949) imperium ini meliputi wilayah Afghanistan, Timur Tengah, China, Asia Tengah, Asia Timur (kecuali Jepang), Georgia, Ukraina, Polandia, Hungaria hingga Bulgaria. Penaklukan dikenal sebagai penaklukan tersukses di dunia lewat darat (Kavaleri binatang ternak) disamping imperium Inggris Raya sebagai penaklukan tersukses lewat jalur laut (Lane, 2004).

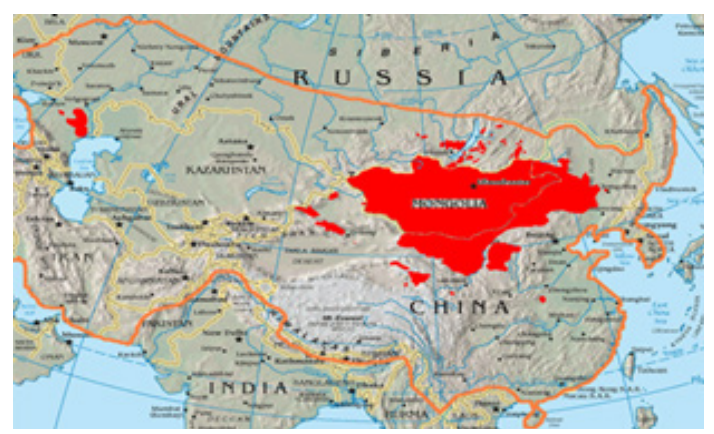

Gambar 7.1. Wilayah Imperium Mongol di Masa Penaklukan dan Negara Mongolia Saat Ini

Sumber: Mc Kinney (2020), Mongols Map-Mongol Empire

Keberhasilan Genghis Khan mengorganisir pasukan menjadikan kekaisaran ini sangat cepat dalam menaklukan daerah-daerah yang menjadi target penguasaannya. Hampir semua peperangan pimpinan Genghis Khan dan keturunannya selalu diwarnai pertempuran-pertempuran berdarah dan mematikan. Kisah penghancuran dinasti Muslim Abbasiyah di Baghdad tahun 1258 mungkin akan dikenang sebagai penaklukan paling dramatis yang pernah ada. Secepat kilat, dinasti yang telah berkuasa hampir 3 abad itu runtuh ketika Hulaghu Khan menyerbu dan menguasainya hingga kejayaan ilmu pengetahuan serta peradaban Islam pun turut meredup (Jackson, 1978).

Namun demikian, fenomena menarik juga didapatkan ketika imperium yang telah dibangun Genghis Khan terutama di wilayah-wilayah China, Persia, Asia Tengah dan Rusia juga berumur relatif pendek yakni 90 tahun hingga sekitar 1 abad saja. Penelitian dari Biran (2019) mengindikasikan bahwa sisa-sisa kebudayaan Mongol sebagai bangsa penakluk yang seharusnya tersisa di daerah-daerah taklukannya hampir sudah tidak dapat dijumpai lagi kecuali di negara Mongolia saat ini yang wilayah telah jauh menyusut dari sebelumnya.

Selain fenomena relatif singkatnya usia negeri Mongol kuno ini, Genghis Khan seperti disampaikan pada penelitian Carl (2012) merupakan tokoh pendobrak aristokrasi dan feodalisme serta mengusung keseteraan dalam pemerintahan melalui sistem meritokrasi yang kuat. Jenghis menghancurkan sistem feodal berdasarkan keistimewaan bangsawan dan menggantinya dengan capaian prestasi, kesetiaan, dan keterikatan dengan hukum.

Diyakini bahwa sepak terjang pasukan Mongol yang gemilang pada masa itu memang tidak luput dari kuatnya karakter sang pemimpin Genghis Khan dalam mempromosikan meritokrasi pada sistem pemerintahan dan militernya. Kaisar yang terlahir dengan nama Temujin, yang berarti "Besi" ini secara jenius telah merancang strategi perang yang nilai strategisnya jauh melampaui masanya. Adanya perencanaan dan misi-misi intelijen juga diyakini sebagai faktor utama dari kesuksesan di hampir semua peperangan tanpa melawatkan kekalahan-kekalahan fatal tersebut. Selain mengorganisir pasukan, kemampuan Genghis Khan dalam menekan serta merusak psikologis pasukan lawan juga menjadi fenomena yang unik.

Keberadaan perang psikologis atau Psychological Warfare memang telah bertranformasi dari waktu ke waktu. Efektivitas perang ini penting dalam mempengaruhi cepatnya kemenangan sebuah pertempuran dapat diraih. Sebagaimana disampaikan Anwar (2021) pada masa perang klasik, seperi kampanye militer Genghis Khan, peran perang psikologis digunakan pasukan Mongol unutk menyebarkan teror dan ketakutan. Selain penaklukan Mongol, pada sejarah Romawi Kuno juga dikenal efektivitas perang psikologis ini ketika terjadi keterbatasan kemampuan tempur. Menurut Różycki (2014) pemimpin militer Romawi pada masa itu terus menyemangati dengan pesan-pesan heroik sehingga bala tentaranya memiliki semangat berlipat ganda di medan pertempuran.

Pada era perang modern pun, eksistensi perang psikologis juga menjadi faktor penting. Dicantumkannya operasi informasi dengan konten psychological warfare dan cyber warfare adalah bukti bahwa perang di masa depan akan lebih banyak beraksi di domain tersebut. Doktri Angkatan Bersenjata Amerika Serikat secara khusus menyebutkan bahwa Psychological Operation (PSYOPS) penting dalam mempengruhi kebiasaan dari pemerintah, grup, aktor, organisasi, dan individu yang terlibat dalam masa perang dan damai (US Department of Defene, 2010). Secara spesifik dinyatkana bahwa 
perang psikologis tersebut merupakan penggunaan propaganda terencana dan tindakan psikologis lainnya yang mempunyai tujuan utama mempengaruhi pendapat, emosi, sikap, dan perilaku kelompok asing yang bermusuhan guna mendukung pencapaian tujuan nasional.

Secara tegas pula, khusus bagi TNI aspek psikologis ini sangat penting dalam fungsi pembinaan kemampuan TNI dalah hal Penangkalan. Pada Doktrin TNI Tri Dharma Eka Karma, fungsi Penangkalan mempunyai aspek psikologis untuk diperhitungkan oleh musuh atau lawan sehingga mereka mengurungkan niatnya untuk melakukan tindakan yang akan mengancam kedaulatan negara, keutuhan wilayah, dan keselamatan bangsa (Keputusan Panglima TNI Nomor Kep/555/VI/2018)

Gerakan intelijen pasukan Mongol harus sabar melewatkan waktu penggalangan hingga puluhan tahun sehingga menghasilkan kemenangan-kemenangan telak. Jenderal Mongol yakni Batu Khan dan Subutai masyhur memiliki satuan intelijen yang mampu menjalankan fungsinya dalam memenangkan perang di wilayah Eropa dan Romawi. Kedua panglima tersebut mengorganisir pasukan dengan jalan membuat dugaan ilmiah tentang kemauan masing-masing kerajaan untuk membantu yang lain, dan kemampuan mereka untuk melawan sendiri atau bersama.

Beberapa pengorganisasian dan taktik dijalankan pasukan Mongol antara lain mengalihkan sungai dari kota, menutup perbekalan ke kota dan menunggu penduduknya menyerah, mengumpulkan warga sipil dari daerah terdekat untuk mengisi garis depan penyerangan kota sebelum memanjat tembok, dan menjarah daerah sekitarnya. Upaya merusak psikis daearah-daerah jajahan dilakukan dengan membunuh beberapa orang, kemudian membiarkan beberapa yang selamat melarikan diri ke pusat kota untuk melaporkan kerugian mereka kepada penduduk utama untuk melemahkan perlawanan, sekaligus menguras sumber daya kota. Berbekal kombinasi dengan perang psikologis yang efektif, hampir semua daerah taklukan selalu didapati kondisi psikologis pasukan lawan sehingga sekutu-sekutu Genghis Khan justru banyak berasal dari pasukan-pasukan yang seharusnya menjadi lawannya.

\section{METODE}

Guna mengeksplorasi terkait analisis tentang peran intelijen dan perang psikologis pada agresivitas kampanye militer kekaisaran Genghis Khan maka ditetapkan bentuk metode historis. Langkah-langkah penelitian tersebut mengacu pada proses metodologi penelitian sejarah yang mengandung empat langkah penting, yaitu: Heuristik, Kritik Sumber, Interperetasi, dan Historiografi (Gottschalk, 1975). Hal ini terkait bahwasannya misi pasukan Mongol secara Time Lines telah berlangsung dalam periode Genghis Khan hingga beberapa cucu dari klan Khan terakhir. Untuk itu perlu adanya upaya analisis yang berangkat dari awal sejarah penaklukan sehingga untuk meng-capture seoptimal mungkin data serta kronologis peristiwa yang ada. Melalui pendekatan tersebut diharapkan akan terkumpul data empririk yang relevan dengan obyek penelitian sehingga mampu menganalisis beberapa dampak dan tren yang akan berkembang dalam menguraikan permasalahan-permasalahan yang terjadi saat ini sebagai upaya antisipatif di masa mendatang (Gay, 1996). Disamping itu, analisis juga akan mengkaitkan beberapa fenomena menarik yang terjadi semenjak sepak terjang Genghis Khan dalam mempersatukan suku-suku Mongol, mengorganisir strategi intelijen dan perang psikologis hingga mencapai kejayaan serta berakhir pada kehancuran yang tragis.

Metode yang digunakan adalah metode historis sebagai proses pengkajian, penjelasan, dan penganalisaan secara kritis terhadap rekaman serta peninggalan masa lampau (Sjamsuddin, 2007). Proses yang terjadi pada pendekatan ini adalah pencarian sumber, penilaian, mengartikan, dan menafsirkan fakta-fakta masa lalu untuk kemudian dianalisis serta didapatkan kesimpulan dari peristiwa sejarah tersebut. Sebagaimana disampaikan Kuntowijoyo (2005), penelitian sejarah mempunyai lima tahap, yaitu: pemilihan topik, pengumpulan sumber, verifikasi, interpretasi: analisia sintesis, dan historiografi. Tahapan tersebut antara lain

Pertama, tahap heuritik dimana peneliti terlebih dahulu mencari sumber-sumber untuk mendapatkan data atau evidensi sejarah (Sjamsuddin, 2007). Pada tahap ini peneliti mulai mencari sumber-sumber data yang relevan dalam penulisan artikel ini. Pencarian dan pengumpulan data ini didapatkan dengan jalan membaca serta mempelajari beberapa data sekunder melalui bahan bacaan artikel pada jurnal nasional maupun internasional, buku, e-book dan produk bacaan lainnya. Upaya tersebut diikuti juga dengan mendatangi perpustakaan dan sumber bacaan untuk kemudian materi yang relevan akan dipilah dan dicatat dari mulai buku, dokumen ataupun artikel yang berhubungan dengan topik penelitian.

Kedua adalah tahap kritik sumber. Pada tahap ini memiliki tantangan tersendiri ketika ini sejarawan dihadapkan pada kesulitan yang sangat besar dalam penelitian sejarah, karena kebenaran sejarah itu sendiri tidak bisa didapatkan secara langsung dan karena sifat sumber sejarah yang tidak lagi lengkap dan sulit 
menemukan sumber-sumber yang diperlukan serta dapat dipercaya (Ismaun, 2005). Tahap kritik sumber mimiliki dua macam kritik yang, yakni kritik eksternal untuk meneliti ontentisitas sumber, dan kritik internal untuk meneliti kredibilitas sumber (Kuntowijoyo, 2005). Oleh sebab itu, sumber yang sudah dikumpulkan akan dipilah melalui dua proses yaitu, kritik eksternal dan internal guna menilai keaslian dan ottentifikasi sumber data atau narasumbernya. Pada langkah ini, peneliti melakukan kritik eksternal terhadap beberapa buku sejarah yang mengulas gearakan ekspansi kekaisaran Mongol dan salah satunya adalah buku berjudul Dari Puncak Barbar Penaklukan Mongol Ke Dunia Islam Hingga Menjadi Muslim karangan Peter Jackson (2019). Buku ini dinilai kredibel karena penulis buku tersebut adalah sejarawan internasional yang professional meneliti terkait sejarah Mongol. Oleh karenanya penulis dinilai mumpuni pengetahuan serta wawasannya dalam memahami sejarah penaklukan imperium Mongol.

Berikutnya adalah tahap interpretasi. Penulis melakukan interpretasi terhadap fakta-fakta yang didapatkan baik dari sumber tertulis. Fakta-fakta yang telah dikumpulkan akan dihubungkan satu dengan lainnya, sehingga setiap fakta menjadi rangkaian peristiwa yang saling berhubungan. Pada tahapan ini dilaksanakan pemilahan dan penerjemahan setiap fakta dan data yang telah diperoleh dan dianggap relevan dalam mendukung penelitian ini. Pada prinsipnya tahap interpretasi ini merupakan langkah antisipasi terhadap penyimpangan data dalam hal relevansinya dengan topik yang akan diteliti dan kemudian dituliskan tersebut.

Tahap terakhir adalah tahap historiografi. dimana seorang sejarawan menggunakan kemampuan daya pikirnya. Upaya tersebut tidak hanya terkait kemampuan penggunaan kutipan, catatan-catatan tetapi juga cara berfikir kritis dan analisanya. Pada akhirnya langkah ini akan menghasilkan pemikiran sintesis dari keseluruhan hasil penemuan atau penelitian secara utuh (Sjamsuddin, 2012). Historiografi sebagai upaya penulisan kembali sejarah merupakan tahapan penelitian, dan pelaporan hasil yang dipaparkan berdasarkan penelitian yang telah dilakukan. Gottschalk (2008) menyatakan bahwa historiografi adalah proses membangun imajinasi dari masa lalu dengan didasarkan pada fakta dan data yang telah didapatkan dengan menggunakan metode sejarah. Sementara itu Abdurahman (2007) menyampaikan bahwa histografi adalah sebuah usaha penelitian dan memaparkan atau pelaporan hasil dari penelitian sejarah. Berdasarkan hal tersebut, maka dapat dikatakan bahwa historiografi merupakan langkah yang dilakukan oleh peneliti untuk berimajinasi dalam rangka mengkontruksi peristiwa-peristiwa atau kejadian di masa lampau agar dapat didajikan kesimpulan dalam bentuk tulisan sejarah.

Guna mendapatkan theoritical sense yang lebih tepat maka pengumpulan data dari berbagai responden. Penelitian sejarah yang menitikberatkan pada proses wawancara memerlukan kejelian menetapkan responden atau narasumber. Sebagian adalah responden yang memiliki latar belakang ahli sejarah militer, sejarawan perang klasik, dosen ilmu sejarah perang hingga dosen strategi pertahanan kontemporer. Kesemuanya merupakan expert advice. Sebagai sample terhadap unit analisis akan tepat dalam merepresentasikan efektifitas pasukan Mongol dalam menaklukan bangsa-bangsa koloninya.

Analisis penelitian sejarah tetap memenuhi kaidah penelitian kualitatif yang menerapkan prinsip validitas data diantaranya construct validity dimana penelitia akan membuktikan bahwa sebuah penelitian kualitatif bukanlah penelitian yang subyektif. Penelitian kualitatif harus memiliki derajat kesesuaian dengan teori atau definisi yang ada selayaknya sebuah penelitian ilmiah. Hal ini akan menjadikan sebuah penelitian kualitatif memiliki obyektifitas yang kuat berdasarkan teori yang ada (theoretical sense). Pada interval validity, proses triangulasi adalah faktor yang terpenting baik yang berdasarkan keragaman sumber data, investigator, lokasi dan sebagainya (Denzin dan Lincoln, 1994).

Oleh sebab itu peneliti melakukan pengumpulan data primer maupun sekunder yang valid dari berbagai responden yang juga reliable tingkat kepakarannya. Sedangkan external validity, peneliti akan membuat hasil penelitian yang mampu digeneralisir sebagai perspektif umum dari objek penelitian bahkan mampu diatribusi pada peristiwa sejarahlainnya. Guna mencapaireliabilitas data yang tinggi, penelitan kualitatif sejarah dengan metode interpretasi akan mengkonfirmasi hasil olahan datanya berdasarkan proses Triangulasi baik terkait, metode, sumber responden dan waktu sehingga akurasi hasil penelitiannya dapat dipertanggungjawabkan.

\section{PEMBAHASAN}

Data dan fakta yang dianalisis serta dielaborasi secara spesifik diharapkan akan menghasilkan lesson learned yang dapat diambil manfaatnya guna pengembangan kajian strategi kampanye militer kontemporer. Menjadi tantangan tersendiri ketika Historical Research berdasarkan fenomena sejarah masa lalu harus dapat dianalisis secara akurat guna proyeksi masa depan (Gay, 1996) 


\section{Faktor yang Mempengaruhi Intelijen dan Perang Psikologis}

Beberapa faktor yang dapat mempengaruhi proses intelijen dalam suatu operasi intelijen modern dapat dikelompokkan menjadi beberapa bagian, antara lain medan dan iklim, infrastruktur, kerahasiaan berita dan regulasi (Thambrata, 2012). Jika mempelajari petualangan bangsa Mongol ketika menaklukan negerinegeri jajahannya, akan ditemukan hal menarik yakni sebaran pasukan ini dapat menyasar daerah-daerah yang berbeda kondisi iklim serta medannya.

Jika dijabarkan lebih lanjut, keterkaitan antara faktor keberhasilan operasi intelijen dan perang psikologis terhadap keberadaan medan operasi yakni bahwa medan tersebut dapat memperkuat proses intelijen yang mengalihkan sumber daya dan perhatian kepada dukungan bagi para pasukan di medan tempur secara berjangka panjang (Jemadu, 2007). Oleh karena itu, peran intelijen dapat menjadi sangat penting dalam pembuatan keputusan dan tindakan pasukan Genghis Khan dalam mengenali situasi dan kegiatan dari bakal negeri-negeri yang akan diokupasinya. Namun, sesuai kaidah operasi intelijen, kegiatan pengumpulan data dan analisa intelijen prajurit Mongol tetap menjadi misi yang memerlukan kekuatan komando dari jenderal-jenderal di medan tempur. Berbekal perencanaan, kesabaran dan penguasaan medan yang dominan, menjadi faktor yang penting ketika hampir seluruh penghancuran wilayah yang dilalui Mongol tanpa ada perlawanan berarti.

Menghubungkan efektivitas intelijen dengan pengaruh medan dan iklim, maka penggunaan intelijen akan memahamkan pasukan Mongol akan pentingnya intelijen dengan keberhasilan operasi. Potensi yang dimiliki intelijen ini utamanya adalah untuk menggali informasi dan mengenali musuh. Hal ini filosof dan ahli strategi Sun Tzu (Laszlo, 2000) mengatakan:

...siapa yang memiliki pengetahuan mendalam tentang diri sendiri dan diri musuhnya, akhirnya akan memenangkan semua pertempuran. Siapa yang mengenal diri sendiri, tetapi tidak mengenal diri musuhnya, hanya mempunyai peluang sama besar untuk menang. Siapa yang tidak mengenal diri sendiri atau diri musuhnya akan kalah di semua medan pertempuran....Kenali musuhmu dan dirimu, maka kemenangan takkan tergoyahkan, dan dengan mengenal medan dan cuaca, kemenanganmu akan lengkap

Sebagaimana pemikiran filsuf dan ahli militer klasik Sun Tzu bahwa mengenali lawan adalah hal yang utama. Setiap ingin menghancurkan lawan perlu mengetahui titik lemah, sifat dan sistem kepemimpinannya, orangorang kepercayaannya, daya dukung yang dimiliki baik yang berasal dari diri sendiri atau diperoleh dari sumbersumber lain, termasuk sumber daya manusia, keuangan, kesenjataan, bahan baku. Dengan memiliki pengetahuan tentang kelemahan atau kekuatan lawan, artinya sudah setengah berhasil menaklukkan lawan. Oleh sebab itu, efektivitas operasi intelijen pasukan Genghis Khan begitu superior ketika peran intelijennya berjalan secara sistematis.

Selain faktor iklim dan medan, fakta menarik yang masih terkait iklim dan medan bahwa ada kontradiksi teoritis. Walaupun secara fisiologis, orang-orang Mongol lebih banyak mendiami wilayah Asia Tengah dengan iklim hangat dan basah, namun ternyata budaya nomaden yang membuat gerak Genghis Khan dan prajuritnya seakan tanpa batas. Faktor iklim pada kasus tersbut seakan bukan penghalang terhadap keberhasilan intelijen dan perang psikologis. Sebut saja, ketika pasukan Mongol menduduki wilayah-wilayah stepa di Rusia, maka secara hampir bersamaan kelompok lain dapat menundukkan Xia Barat, Dinasti Jin dan Dinasti Song di China antara tahun 1209-1279. Di penjuru lainnya, pasukan-pasukan berkuda Mongol tanpa ampun menghancurkan teritori beriklim dingin di Eropa Timur, Siberia hingga Turki.

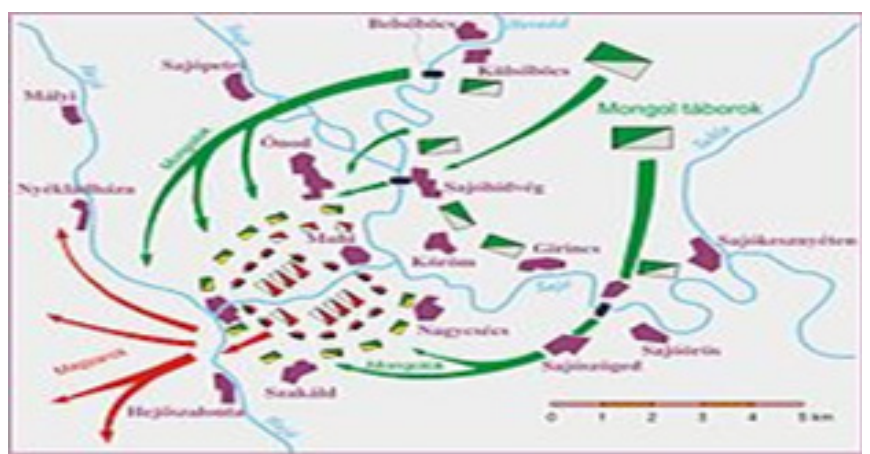

Gambar 7.2. Pola Serangan Mongol dalam Battle of Mohi di Sungai Sajo Hungaria

Sumber: Ervin (1985), Military History of Hungary

Pertempuran Mohi di tahun 1241 adalah bukti kehebatan kekaisaran Mongol mampu meluluh lantakkan Hungaria meskipun dalam kondisi musim dingin. Kemenangan pada Battle of Mohi semakin tak membendung ambisi Subutai, salah satu jenderal terbaik Mongol untuk menguasai Eropa Timur secara keseluruhan (Laszlo, 2000).

Peperangan di masa lalu, membuat keberadaan intelijen hanya mengandalkan infrastruktur dan sumber daya manusia saja. Situasi ini terkait dengan sumber daya militer di masa lalu termasuk kekaisaran Mongol yang saat itu belum mengenal teknologi sistem komunikasi dan informasi seperti saat ini.

HISTORIA: Jurnal Pendidik dan Peneliti Sejarah, p-issn:2620-4789 | e-issn:2615-7993 
Belum terpenuhinya teknologi tersebut, praktis sistem komando dan kendali pasukan masih sangat sederhana termasukoperasi intelijen yang hanya dipenuhi lewat manuver-manuver prajurit dalam memanfaatkan penguasaan medan, keterampilan keprajuritannya semata dan kekuatan leadership Genghis Khan di masa awal imperium ini. Kehandalan prajurit Mongol dengan kemampuan mobilitas tinggi serta ketangguhan penguasaan medannya menopang kesabaran para aktor intelijen sehingga terbukti efektif ketika harus selama berpuluh tahun menyatu dengan masyarakat di wilayahwilayah akan menjadi taklukannya. Sebagaimana disampaikan Ratchnevsky (1991) kehandalan pasukan Mongol membuktikan bahwa berbekal kepemimpinan para panglima Mongol yang tangguh, turut membentuk kemahiran prajurit di bidang seni pertempuran dan intelijen. Sementara kebengisan dalam menghabisi setiap lawan adalah representasi dari tempaan alami sebagai bangsa nomaden yang selalu diwarnai konflikkonflik kesukuan.

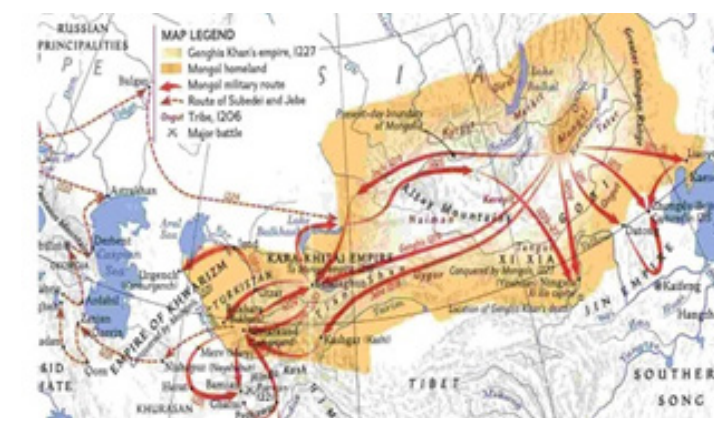

Gambar 7.3. Sebaran Serangan Pasukan Genghis Khan Sumber: https://historiarex.com

Sebagai ilustrasi, sebelum invasi ke Eropa, Batu dan Subutai, militer Mongol telah mengirim matamata selama hampir sepuluh tahun ke jantung Eropa, membuat peta dari jalan-jalan Romawi, melihat rute perdagangan, dan menentukan tingkat kemampuan masing-masing kerajaan untuk melawan invasi. Hasil dari kesabaran itu adalah taktik serbuan kilat pasukan Mongol menghabisi setiap wilayah koloninya.

Terkait masalah kerahasiaan berita dan aturan peperangan, hal ini berhubungan dengan generasi peperangan dengan klasifikasi (Lind, et.al., 1989):

1. Peperangan generasi pertama mengacu pada pertempuran Kuno dan Pasca-klasik yang bertempur dengan banyak tenaga, menggunakan taktik alat perlindungan tameng, garis dan kolom dengan tentara berseragam yang diatur oleh negara.

2. Peperangan generasi kedua adalah taktik modern awal yang ditandai dengan penemuan senapan dan senjata dan berlanjut melalui pengembangan senapan mesin dan tembakan tidak langsung. Istilah perang generasi kedua diciptakan oleh militer AS pada tahun 1989.

3. Peperangan generasi ketiga berfokus pada penggunaan taktik yang diturunkan dari teknologi modern akhir untuk meningkatkan kecepatan dan teknologi material siluman, untuk melewati garis musuh dan menghancurkan pasukan dari belakang. Pada dasarnya, ini adalah akhir dari peperangan linier pada tingkat taktis, dengan unit-unit yang berusaha tidak hanya untuk bertemu satu sama lain secara langsung tetapi untuk saling bersiasat mendapatkan keuntungan terbesar.

4. Peperangan generasi keempat seperti yang disajikan oleh Lind et al. dicirikan oleh kembalinya "post-modern" ke bentuk-bentuk perang yang terdesentralisasi, kaburnya garis antara perang dan politik, kombatan dan warga sipil karena hilangnya negara-bangsa atas dominasi dari hampir-seluruh kekuatan pasukan tempur.

Oleh sebab itu, jika merujuk pada generasi perang di atas, maka era dinasti Genghis Khan dan para klannya berada pada teknologi perang generasi ke1. Secara umum selain peran intelijen, kemampuan perang psikologi Mongol juga membawa nilai strategis tersendiri. Salah satu kekhasan psywar-nya adalah memancing musuh untuk menyerang ke posisi yang rentan, kemudian menghilang ke dalam hutan atau di balik bukit sementara pasukan sayap Mongol yang sudah berada di posisi strategis akan muncul entah dari kiri, kanan dan/atau dari belakang pasukan lawannya.

Pendadakan tersebut umumnya berakhir dengan pembantaian brutal ke penduduk negeri-negeri koloni kekaisaran Mongol. Tindakan prajurit Mongol tersebut benar-benar sukses merusak psikis dan mental lawan. Ketika pasukan Mongol membiarkan sebagian penduduk dengan sengaja untuk tidak dihabisi seluruhnya, sematamata hanya sebagai cara menebar teror ke wilayah yang menjadi tempat pelarian para pengungsi tersebut.

\section{Kejayaan dan Keruntuhan Kekaisaran Mongol}

Gerak agresif bangsa Mongol dalam membumi hanguskan setiap daerah yang dilewati memang semakin tak terbendung. Penaklukan demi penaklukan tidak pernah berhenti ketika para klan keturunan Genghis Khan seperti Jochi, Ilkhanat, Chagatai dan Golden Horde (Gerombolan Emas) semakin meluaskan daerah-daerah kekuasaan imperium Mongol terutama di wilayah Rusia, China, Persia, Asia Tengah hingga anak benua India. Strategi pertempuran modern yang dikombinasikan dengan kuatnya leadership para jenderal pasukan Mongol adalah kunci kisah kesuksesan bangsa Mongol. 
Tingkat keberhasilan penaklukan Mongol dapat dilihat dari beberapa indikator antara lain luasnya wilayah koloni, kecepatan serbuan hingga efektivitas sistem meritokrasi dalam struktur organisasi militer maupun pemerintahan (Manz, 2011). Keberadaan luasnya cakupan imperium dan taktik sapuan kilat Mongol memang menjadi hal mengagumkan dalam sejarah peperangan dunia. Semakin menarik lagi ketika sistem meritokrasi yang awalnya dipandang skeptis karena melawan kebiasaan aristokrasi Asia justru membawa kegemilangan bagi Mongol. Banyak dijumpai bahwa ternyata para panglima perang Mongol yang pada awalnya adalah musuh-musuh Genghis Khan berbalik mendukung ketika berhasil dikondisikan dengan sistem meritokrasi ini.

Ketangguhan pasukan Mongol terus menunjukkan dominasi ketika akhirnya di sekitar tahun 1260, berawal dari terdesaknya prajurit-prajurit Mongol dalam menghadapi pasukan Muslim Mamluk, tanda-tanda kemunduran mulai nampak. Ekspedisi demi ekspedisi tidak mendapatkan hasil baik ketika gerak maju Mongol gagal menguasai Jepang, sebagian Eropa Timur dan Eropa Barat. Memang tidak seluruhnya kegagalan itu disebabkan taktik militer, terhentinya laju ekspansi ke Eropa Barat diyakini karena sang kaisar saat itu Ogadai Khan meninggal dunia di tahun 1242. Paling tidak ada 3 faktor yang menyebabkan kekaisaran Mongol sirna antara lain konflik internal, perubahan visi dari perang psikologis dan munculnya kekuatan baru.

Walaupun kekaisaran Mongol berjaya dengan sistem meritokrasi yang diwariskan Genghis Khan namun ternyata upaya ini tidak sepenuhnya diterima fihak klan lainnya. Puluhan pemberontakan dan perang saudara pecah yang mengakibatkan ketidakstabilan pemerintahan Mongol. Kebijakan Genghis Khan yang membagi wilayah Mongol menjadi empat kekuasaan untuk putra dan kerabatnya seolah menjadi pintu masuk meluasnya upaya pemberontakan tersebut.

Pada saat itu, berkuasa empat imperium Mongol yang masyhur yakni Jochi/Yuan (Cina), Kekhanan Chagatai (Asia Tengah), Ikhanate (Timur Tengah) dan The Golden Horde (Eropa). Kekalahan Mongol di Ain Jalut oleh pasukan muslim Malmuk, kegagalan Kubilai Khan menundukkan Jawa dan mundurnya prajurit Mongol di jazirah Arab dan Israel adalah indikasi kekuatan pasukan tersebut sudah menurun. Ironisnya keporak-porandaan Mongol kala itu justru disebabkan dua aktor kerabat Khan yang lain, yakni Berke Khan yang menghalau Hulaghu Khan di Timur Tengah dan Timurleng menamatkan riwayat pasukan Chagatai Khan di Asia Tengah.
Selain rongrongan pengkhianatan yang terus menerus menerpa dinasti Khan, semakin lama agresivitas para panglima Mongol sudah tidak seberingas sebelumnya. Ada semacam pergeseran visi perang psikologis yang terjadi di masa akhir kekaisaran Mongol. Daya dobrak kampanye militer pasukan Mongol untuk menghabisi secara total seluruh daerah yang akan dijarahnya seolah mulai mengendur ketika terjadi interaksi sosial budaya. Di Cina, bangsa Mongol semakin membaur dengan suku asli bangsa Han. Mereka bahkan juga turut menyerap kepercayaan orang Cina, seperti ajaran Konfunsianisme, Taoisme ataupun Buddha, dan meninggalkan Shamanisme serta Tengirisme ataupun ajaran pagan asli nenek moyang mereka.

Di India, Asia Tengah dan Persia, orang Mongol justru menjadi Muslim. Mereka bahkan memiliki andil penting dalam mengembangkan kerajaan-kerajaan bercorak Islam di wilayah tersebut. Pada masa itu berjaya satu dinasti Muslim yang sangat luas wilayahnya yakni Kesultanan Mughal (sebutan Mongol dalam versi Indo-aryan) yang berkuasa lebih dari 2 abad di wilayah Hindustan, Asia Selatan. Lamanya Dinasti Mughal bahkan lebih panjang dari masa pemerintahan imperium Mongol sebagai bangsa leluhurnya.

Kegagalan Mongol menaklukan beberapa wilayah seperti Volga Bulgaria di tahun 1223, Dai Vet tahun 1257, 1285 \& 1288 dan Champa (Vietnam) tahun 1283 adalah bukti bahwa bala tentara tersebut juga tidak luput dari kekalahan-kekalahan tragis. Negeri-negeri yang memiliki strategi bertempur, geografis dan sekutu yang kuat menjadi lawan terberat Mongol. Taktik serangan darat, pengepungan dan berbagai upaya intelijen serta disepsi pada kampanye militer Mongol dinilai sudah usang dan mudah dipatahkan. Kehadiran bangsa dan kerajaan besar yang kuat seperti Tsar Rusia, Dinasti Ming di China, Kekhalifahan Islam Turki Utsmani dan Kesultanan Mughal di India turut mempercepat lenyapnya kekaisaran Mongol secara mutlak di abad ke19.

\section{SIMPULAN}

Kekaisaran Mongol akan selalu dikenang bahwa kejayaan dan kehancuran negeri yang besar karena pertempuran akan membawa pelajaran tersendiri terutama dari aspek strategi militer. Ada pun kesimpulan dari kisah penaklukan Imperium Mongol terkait peran intelijen dan perang psikologis antara lain bahwa kesuksesan bangsa Mongol memperluas dan menancapkan dominasi di wilayah jajahannya diawali oleh faktor kecerdikan Genghis Khan dalam menggalang proses intelijen dan perang psikologis 
yang menyandarkan diri dari unsur medan dan iklim, infrastruktur, kerahasiaan berita dan regulasi.

Disamping itu taktik pertempuran kavaleri darat para panglima perang Mongol terkait pengepungan, serangan lambung, desepsi, tipu muslihat dan pemberangusan serta penjarahan yang dikombinasikan dengan leadership dan sistem Meritokrasi adalah kunci keberhasilan Mongol dalam setiap pertempurannya dengan hasil gemilang. Pada akhirnya Kekaisaran Mongol yang efektif dengan serangan cepatnya ternyata tidak cukup berhasil mempertahankan kelanggengan kekuasaannya. Paling tidak ada 3 faktor yang menyebabkan kekaisaran Mongol lenyap antara lain konflik internal para klan dinasti Khan, perubahan visi dari perang psikologis akibat alkulturasi budaya dan munculnya bangsa-bangsa baru yang lebih tangguh dalam memanfaatkan aliansi militer, keunggulan geografis serta strategi perang yang lebih modern.

\section{REFERENSI}

Anwar, S. (2021). Materi mata kuliah sejarah perang: invasi dan penaklukan mongolia: genghis khan dan strategi peperangan. Jakarta: Unhan RI.

Biran, M (ed.). (2019). Mobility Transformations and cultural exchange in mongol eurasia. Journal of the Economic and Social History of the Orient, 62(2-3), 257-268.

Carl, B. M. (2012). The laws of genghis khan. Law and Business Review of the Americas, 18(2), 147.

Cleves, F.W (1949). The mongol names and terms in the history of the nation of the archers by grigor of akanc. Harvard Journal of Asiatic Studies, 12, 400443.

Deibel, T. L. (2014). Foreign affairs strategy: logic for american statecraft. The National War College: Cambridge University Press.

Denzin, N. K. \& Lincoln, Yvonna S. (1994). Handbook of qualitative research. Sage Publications.

Gay, L.R (1996). Educational research: competencies for analysis and application, Retrieved March 7, 2021, diakses dari http://www.cedu.niu. edu/ sorensen/502. pada tanggal 6 Maret 2021

Jackson, Peter (2017). Dari puncak barbar, penaklukan mongol ke dunia islam hingga menjadi muslim. Jakarta: PT. Serambi Ilmu Semesta.

Jackson, Peter (1978). The dissolution of the mongol empire. Central Asiatic Journal, 22(3/4), 186-244.

Jemadu, A. (2007). Praktek-Praktek intelijen dan pengawasan demokratis-pandangan Praktis, Kelompok Kerja Intelijen DCAF, Geneva Centre For The Democratic Control of Armed Forces (DCAF), Publikasi DCAF-FES SSR Vol. II
Keputusan Panglima TNI Nomor Kep/555/VI/2018, Doktrin TNI Tri Dharma Eka Karma

Lane, G. (2004). Genghis khan and mongol rule. Westport, CT: Greenwood

László, Markó (2000). Great honours of the hungarian state. Budapest: Magyar Könyvklub.

Lind, W. S., Nightengale, K., Schmitt, John F., Sutton, Joseph W., Wilson, Gary I. (1989). The changing face of war: into the fourth generation. Marine Corps Gazette, pp. 22-26

Liptai, E. (1985). Military history of hungary. Budapest: Zrínyi Katonai Kiadó.

Lykke Jr. A. F. (1998). Military strategy: theory and application carlisle. PA: U.S. Army War College.

Manz, B. F. (2011). The new cambridge history of islam. Cambridge University Press.

Mutopo, W. I. (2017). Psychologycal operations (psyops) adalah untuk memenangkan hati dan pikiran masyarakat. Diakses dari https://www.kemhan. go.id, diakses pada tanggal 13 Maret 2021.

Ratchnevsky, P. (1991). Genghis khan: his life and legacy [Čingis-Khan: sein Leben und Wirken]. Thomas Nivison Haining. Oxford, UK; Cambridge, Massachusetts, US: B. Blackwell.

Rolington, Alfred (2013). Strategic intelligence for the 21st century: the mosaic method. Oxford University Press.

Różycki, Ł. (2014). Fear-elements of slavic psychological warfare in the context of selected late roman sources. Journal of Ancient History and Archeology, 2(1).

Stark, B. (2016). Intelligence 101: the intelligence cycle: an introduction to direction, collection, analysis \& dissemination of intelligence, diakses dari http:// www.intelligence101.com. Pada tanggal 13 Maret 2021.

Sternberg, R. J. (2019). A theory of adaptive intelligence and its relation to general intelligence. Journal of Intelligence. 7(4), 23.

Thambrata (2016). Artikel pertahanan: intelijen untuk kepentingan pertahanan negara. Lembaga Kajian Pertahanan Strategis (Keris), https://lembagakeris. net.

Tippe, S. (2017). Ilmu pertahanan: sejarah, konsep, teori dan implementasi. Depok: Penerbit Salemba Humanika.

Townshend, C. (2000). The oxford history of modern war. Oxford University Press.

Wahyuni, S. (2012). Qualitative research method: theory and practice. Jakarta: Penerbit Salemba Empat.

Yin, R.K. (2003). The case study research design and methods. London, Sage Publication Inc. 